\title{
Managing Water in the West: Developing New Tools for
} a Critical Resource

\section{Rapid population growth in the Western United States over the last century has placed increasing strains on our water supplies and aquatic ecosystems. Historically, water rights have been used to determine the allocation of water in the West, but rules and regulations related to endangered species now often drive how water is released from reservoirs in large rivers such as the lower Colorado and the Columbia. In numerous smaller watersheds, communities are trying to balance the water necessary for human use, irrigation, and the conservation of ecosystems.}

To assist managers in the face of increasing complexity and uncertainty in water management decisionmaking, the Western Fisheries Research Center (WFRC) is involved in developing a new generation of integrative tools. Below are some examples of the types of tools that already exist within the WFRC.

\section{Modeling Streams and Rivers}

Hydraulic models of streams and rivers can now be built at very fine scales - inches or feet - and then adapted to model the habitat of stream fishes. Researchers collect field data, construct habitat preference models that include water depth, water velocity, and other variables, and interweave these with the hydraulic models. The combined approaches are used to predict broad variations in fish habitat across a wide range of flows caused by upstream dam operations, natural variability, climate change, and other factors. The WFRC has developed and applied these types of habitat models for analysis of juvenile
Chinook salmon (Oncorhynchus tshawytscha) rearing in the Hanford Reach of the Columbia River and for adult chum salmon (O. keta) spawning below the Bonneville Dam in the lower river. Plans are underway to develop a similar model for fish in the Yakima River Basin to help agencies evaluate a potential new reservoir that would increase irrigation reserves for southern Washington.

\section{Warm Water Fish get Help}

The Moapa dace (Moapa coriacea) is an endangered fish species that occurs only in warm springs and streams that feed into the Muddy River in southern Nevada near Las Vegas. These small, unique fish live in waters whose temperatures range from 26 to $32^{\circ} \mathrm{C}\left(79-90^{\circ} \mathrm{F}\right)$ - such fish are called "thermal endemic" species, meaning that they require warm water to survive. The persistence of the Moapa dace has recently been jeopardized, however, by human activities. First, the headwaters of the Muddy River were invaded by the nonnative blue tilapia which are known herbivores but switched to eating Moapa dace once all the aquatic vegetation was gone, eliminating them from $90 \%$ of their native range. Secondly, spring flow in the $10 \%$ of the habitat not invaded by blue tilapia is declining due to pumping of the nearby groundwater (the carbonated aquifer), the source of the spring flow. Reduction in 
spring flow is anticipated to lessen habitat quantity and quality through reduction of water volume and the extent of optimum thermal habitat. Biologists from the WFRC were contracted by the U.S. Fish and Wildlife Service to collect pertinent data and develop a model aimed at predicting the persistence of Moapa dace under various changing environmental conditions. The new generation model, along with field and laboratory data, will include evaluations of habitat effects on movements, behavior, growth, and respiration of the fish, and will be a useful tool to manage and protect Moapa dace.

\section{Internet Tools}

The WFRC is developing a set of internet mapping applications that will allow scientists and the public to query and view important landscape features or species' habitats of concern. In the Hanford Reach of the

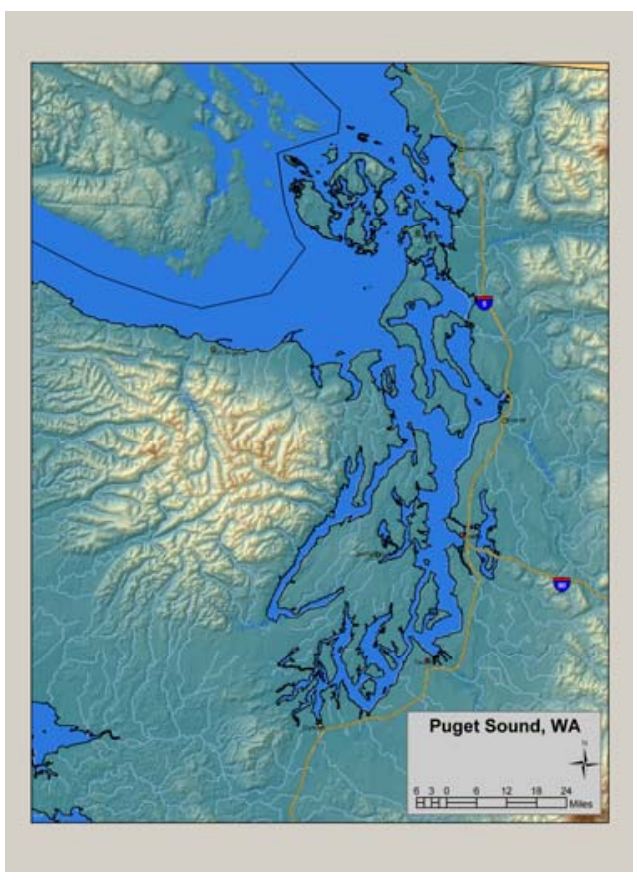

Satellite image of Puget Sound, WA.



Example of using hydrodynamic models and fisheries habitat data to illustrate changes in habitat that could be expected under different water level elevations in a Columbia River reservoir.

Columbia River, one of the last free-flowing segments of the river and the most important spawning habitat of fall Chinook salmon, we have developed an internet mapping application that lets users select one or more stream flows and then view potential rearing habitat of subyearling Chinook salmon. In the John Day Reservoir of the Columbia River, we have developed an internet mapping tool that allows users to examine potential white sturgeon or Chinook salmon spawning habitat at a selected river discharge. Our next big challenge is the development of an internet mapping tool that will allow users to query and display important fish habitats throughout Puget Sound and identify gaps in the conservation of target species. Other areas we hope to develop are internet mapping applications for the Klamath Basin in southern Oregon and the Columbia River estuary.

\section{What Comes Next?}

The USGS and the WFRC are beginning discussions with the Department of the Interior partners and other parties in the West to determine the need for new models and the types of tools that would be most useful. A series of workshops have begun across the region to obtain input from the Department of the Interior partners, identify technical expertise within USGS, and describe the types of models that would be most appropriate. The new generation of integrative tools will build on existing techniques to address the complex issues of changing stream flow, groundwater availability, climate conditions, and water quality, and allow managers to forecast the biological and habitat effects of these changes.

For additional information, please contact:

Lyman Thorsteinson, Center Director

U.S. Geological Survey

Western Fisheries Research Center 6505 NE $65^{\text {th }}$ Street, Seattle, WA 98115 (206) 526-6282 ext. 236

FAX (206) 526-6654 